(C) B.I. Ряшко, М.I. Фатула, 2019

УДК 616.127-005.8.

\title{
Лікування паціснтів із гострим інфарктом міокарда в Мукачівській центральній районній лікарні (Україна) та в Кардіологічному центрі в Банській Бистриці (Словацька Республіка)
}

\author{
B.I. Ряшко, М.I. Фатула \\ rjashkomk@ukr.net
}

Ужгородський начіональний університет, медичний факультет, кафедра факультетської терапії, Уэсгород

\section{Реферат}

Вступ. На сьогоднішній день серцево-судинні захворювання (СС3) є основною причиною смертності в промислово розвинених країнах світу, в тому числі й в Україні. Тому від правильно поставленого діагнозу та своєчасно проведеного лікування залежить життя пацієнтів. Згідно з даними Асоціації інтервенційних кардіологів України, впродовж 2017 року в 11 областях України смертність від гострого інфаркту міокарда (ГІМ) знизилась на 20\% порівняно з 2015 роком. Причиною цього є розбудова реперфузійних центрів у країні та закупівля якісних стентсистем, які надаються пацієнту при ургентних випадках безкоштовно.

Мета дослідження. Дослідити принципи лікування хворих на гострий інфаркт міокарда в Україні та Словацькій Республіці, порівняти показники смертності від даної патології за останні 6 місяців та знайти оптимальні методи лікування, які продовжать життя таких пацієнтів.

Матеріали та методи. Опрацьовано 100 стаціонарних карт пацієнтів із СС3, які поступили за останні 6 місяців до кардіологічного центру в Банській Бистриці, що в Словацькій Республіці, та 100 стаціонарних карт пацієнтів із CC3, які поступили за той же проміжок часу до кардіологічного відділення Мукачівської центральної районної лікарні (ЦРЛ), Україна. Відбір стаціонарних карт був механічний, кожна 2 карта у відділенні. Кількість населення у містах майже однакова: у Банській Бистриці - 77000 (у 2017 р.), у Мукачеві - 86000 (у 2016 р.). Обстеження хворих проводили відповідно до уніфікованих клінічних протоколів (накази МОЗ України № 164 від 02.03.2016р. та № 455 від 02.07.2014p.).

Результати досліджень та їх обговорення. У ході дослідження було встановлено, що українські протоколи надання медичної допомоги пацієнтам з ST Elevation Myocardial Infarction (STEMI) та Non-ST Elevation Myocardial Infarction (NSTEMI) відповідають міжнародним, однак показник стаціонарної та 6-місячної смертності залишається вищим, ніж у Словацькій Республіці. Після запровадження в Україні безоплатного стентування в екстрених випадках для пацієнтів із ГІМ смертність знизилась на $28 \%$ порівняно $з$ показниками 5-річної давності, але в той же час показники 6-місячної смертності пацієнтів досі залишаються високими.

Висновки. Для зниження показників летальності від гострого інфаркту міокарда необхідно покращити укомплектування кардіологічні бригади швидкої медичної допомоги, продовжувати розбудову кардіологічних центрів у країні та їх забезпечення необхідним устаткуванням і безкоштовними стентами, внести зміни до діючого протоколу надання медичної допомоги пацієнтам з гострим інфарктом міокарда без елевації сегмента ST, які стосуватимуться до обов'язкового виконання коронарографії в плановому порядку після проведеного лікування.

Ключові слова: гострий інфаркт міокарда, реперфузія, коронарографія, стентування, STEMI, NSTEMI, надання медичної допомоги, смертність.

Evaluation of survival of patients with acute myocardial infarction at hospital in mukachevo (ukraine) and at the cardiological center in banska bystrica (slovakia) on the data of 6-timescent observation Riashko V.I., Fatula M.I.

Uzhhorod National University, Medical Faculty, Department of Faculty Therapy, Uzhhorod, Ukraine.

\section{Abstract}

Introduction. Today cardiovascular disease (CVD) is the main cause of mortality in the industrialized countries of the world, including Ukraine. Therefore, the life of patients depends on the correct diagnosis and timely treatment. According to the Association of Interventional Cardiologists of Ukraine, during the year 2017, mortality from acute myocardial infarction (AMI) in 11 regions of Ukraine decreased by $20 \%$ compared to 2015 . The reason for this is the development of reperfusion centers in the country and the purchase of quality stent systems that are provided to the patient in urgent cases for free.

The aim of the study. To study the principles of treatment of patients with acute myocardial infarction in Ukraine and Slovak Republic, compare the mortality rates of this pathology over the past 6 months and to find the best treatment methods that will prolong the life of such patients.

Materials and methods. Worked 100 stationary cards of cardiac patients treated in the past six months at Banska Bystrica's Cardiology Center in Slovak Republic and 100 stationary cards of cardiac patients who received at the same period of time to the Cardiology Department of the Mukachevo Central Hospital, Ukraine. The selection of stationary cards was mechanical, each second cards at the department. The number of population in cities is almost the same: in Banska Bystrica - 77000 (in 2017), in Mukachevo - 86000 (in 2016). The examination of patients was carried out in accordance with unified clinical protocols (orders of the Ministry of Health of Ukraine No. 164 dated 02.03 .2016 and No. 455 dated 02.07.2014). 
Research results and their discussion. The study found that Ukrainian protocols for the provision of medical care to STEMI and NSTEMI patients are international, but stationary and 6-month mortality rates remain higher than in Slovakia. After the introduction of free stenting in our country in emergency cases, mortality rate for AMI patients has decreased by $28 \%$, compared to 5 years ago, but at the same time the 6 -month mortality rate of patients remains high.

Conclusions. To reduce the mortality rate from acute myocardial infarction it is necessary to improve the staffing of emergency medical teams, to continue to develop cardiology centers in the country and provide them with necessary equipment and free stents, to amend the effective protocol for the provision of medical care to patients with acute myocardial infarction without ST elevation, which will relate to obligatory execution of coronary angiography in the planned order after the treatment.

Key words: acute myocardial infarction, reperfusion, coronary angiography, stenting, STEMI, NSTEMI, medical care, mortality.

Вступ. На сьогоднішній день захворюваність на ішемічну хворобу серця (IXC) в світі, в тому числі і в Україні, - висока і залишається найчастішою причиною смертності серед населення. Тому від правильно поставленого діагнозу та своєчасно проведеного лікування залежить життя пацієнтів. Згідно 3 даними Асоціації інтервенційних кардіологів України, впродовж 2017 року в 11 областях України смертність від гострого інфаркту міокарда (ГІМ) знизилась на 20\% порівняно з 2015 роком. Причиною цього є розбудова реперфузійних центрів у країні та закупівля якісних стент-систем, які надаються пацієнту при ургентних випадках безкоштовно [5].

Мета дослідження. Дослідити принципи лікування хворих на гострий інфаркт міокарда в Україні та Словацькій Республіці, порівняти показники смертності від даної патології за останні 6 місяців та знайти оптимальні методи лікування, які продовжать життя таких пацієнтів.

Матеріали та методи. Опрацьовано 100 стаціонарних карт пацієнтів із СС3, які поступили за останні 6 місяців до кардіологічного центру в Банській Бистриці, що в Словацькій Республіці, та 100 стаціонарних карт пацієнтів із СС3, які поступили за той же проміжок часу до кардіологічного відділення Мукачівської ЦРЛ, Україна. Відбір стаціонарних карт був механічний, кожна 2 карта у відділенні. Кількість населення у містах майже однакова: у Банській Бистриці - 77000 (у 2017 р.) у Мукачеві - 86000 (у 2016 р.).

Обстеження хворих проводили відповідно до наказу МО3 України № 164 «Уніфікований клінічний протокол екстреної, первинної, вторинної (спеціалізованої) та третинної (високоспеціалізованої) медичної допомоги та медичної реабілітації - гострий коронарний синдром без елевації сегмента ST» від 03.03.2016 р., та наказу MO3 України № 455 «Уніфікований клінічний протокол екстреної, первинної, вторинної (спеціалізованої) та третинної (високоспеціалізованої) медичної допомоги та медичної реабілітації

- гострий коронарний синдром 3 елевацією сегмента ST» від 02.07.2014 p. Обидва протоки відповідають міжнародному зразку лікування пацієнтів з STEMI та NSTEMI $[1-4,6]$.

Результати досліджень та їх обговорення. Дослідивши структуру захворюваності СС3 в кардіологічному центрі в Банській Бистриці, ми отримали такі результати:

$>88$ пацієнтів страждають на ГХ (88\%);

> 79 пацієнтів страждають на IXC (79\%);

> 74 пацієнти мають в анамнезі IM (74\%).

- STEMI - 31 пацієнт (42\%);

- NSTEMI - 43 пацієнти (58\%).

Були відібрані тільки пацієнти з діагнозом гострий інфаркт міокарда.

При поступленні кожен 374 пацієнтів з ГІМ (незалежно від того, який вид інфаркту в нього діагностовано: SNEMI чи NSTEMI) отримав таку фармакотерапію:

$\checkmark$ anopirin (аспірин) - 2 табл. по 100 мг - антиагрегант;

$\checkmark$ briligue (тікаглерол) - 2 табл. по 90 мг - антитромботичний засіб;

$\checkmark$ sortis (аторвастатин)- 1 табл. по 80 мг - статин;

$\checkmark$ fraxiparin (фраксипарін) - 0,1 мг на 10 кг ваги хворого - антикоагулянт.

Усім пацієнтам із STEMI було виконано коронарографію із подальшим стентуванням ураженої судини (тромболізисна терапія не є варіантом вибору у цій лікарні через численні протипокази та загрозу кровотеч після проведення процедури).

Серед пацієнтів з NSTEMI за шкалою GRACE (Global Registry of Acut Coronary Events13 мали низький ризик летальності (отримали лише фармакотерапію), 21 - середній, 9 - високий ризик (цим пацієнтам було виконано черезшкірне коронарне втручання (ЧКВ).

Стаціонарна та 6-місячна летальність пацієнтів з ГІМ у цій лікарні показана в табл. 1 .

Таблиця 1

Дані смертності від гострого інфаркту міокарда в кардіологічному центрів Банської Бистриці, Словацька Республіка

\begin{tabular}{|c|c|c|}
\hline & Стаціонарна летальність (\%) & 6-місячна летальність (\%) \\
\hline STEMI & 3,1 & 6,45 \\
\hline NSTEMI & 2,32 & 6,98 \\
\hline
\end{tabular}


Дослідивши структуру захворюваності на СС3 у кардіологічному відділенні Мукачівської ЦРЛ, отримали такі результати:

> 92 пацієнти страждають на ГХ (92\%);

> 76 пацієнтів страждають на IXC (76\%);

> 59 пацієнтів мають в анамнезі IM (74\%).

- $\mathrm{STEMI} \mathrm{-} 34$ пацієнти (58 \%);

- NSTEMI - 25 пацієнтів (42\%).

При поступленні кожен 3 цих 59 пацієнтів (незалежно від того, який вид інфаркту в нього діагностовано: SNTEMI чи NSTEMI отримав таку фармакотерапію:

$\checkmark$ аспірин - 500 мг - антиагрегант;

$\checkmark$ брилінта (тікаглерол) - 2 табл. по 90 мг антитромботичний засіб; фленокс (еноксапарін) - 0,8 мл - антикоагулянт;

$\checkmark$ аторвастатин - 80 мг - статин.

Усі пацієнти зі STEMI були направлені в Ужгород, до обласного кардіологічного диспансеру (враховуючи "золоту годину“ - перші 60 хвилин), де їм було виконано перкутантні коронарні втручання [5].

Серед пацієнтів, у яких було діагностовано NSTEMI, до Ужгорода для проведення коронарографії було направлено 6 пацієнтів, інші 19 отримали лише фармакотерапію.

Стаціонарна та 6-місячна летальність пацієнтів з ГІМ серед усіх пацієнтів із ГІМ у Мукачівській ЦРЛ за даними дослідження показана в табл. 2.

Таблиця 2

Показники смертності від гострого інфаркту міокарда у кардіологічному відділенні Мукачівської ЦРЛ, Україна

\begin{tabular}{|l|c|c|}
\hline & Стаціонарна летальність (\%) & 6-місячна летальність (\%) \\
\hline STEMI & 8,8 & 11,76 \\
\hline NSTEMI & 8 & 12 \\
\hline
\end{tabular}

Як бачимо, статистичні дані щодо смертності пацієнтів від ГІМ в українській лікарні є вищими, ніж в лікарні Словацької Республіки. Поясненням цьому можуть бути декілька причин, у тому числі недостатне забезпечення кардіологічних бригад швидкої допомоги препаратами на догоспітальному етапі (табл. 3).

Таблиця 3

Надання медичної допомоги хворим на гострий інфаркт міокарда на догоспітальгому етапі

\begin{tabular}{|c|c|c|}
\hline Препарати & Банська Бистриця & Мукачево \\
\hline Аспірин, мг & 200 & 200 \\
\hline Клопідогрель, мг & 600 & - \\
\hline Еноксапарин, мг/кг & $0,1 \times 10$ кг & - \\
\hline Статини, мг & 80 & - \\
\hline
\end{tabular}

Як бачимо, у Словацькій Республіці пацієнту з ГІМ основну фармакотерапію проводять на догоспітальному етапі, в той же час як в Україні стаціонарно пацієнт отримує більшу частину препаратів.

У Словацькій Республіці пацієнту з NSTEMI, якому не було проведено ургентного ЧКВ через відсутність показів, коронарографію виконують у плановому порядку з метою виключення стенозу чи оклюзії коронарної артерії або іiі гілок у майбутньому.

Якщо порівнювати показники смертності пацієнтів з ГІМ в Мукачівській ЦРЛ за останні 5 років, то показник стаціонарної летальності знизився на 28\%, 6-місячної - на 15\%.

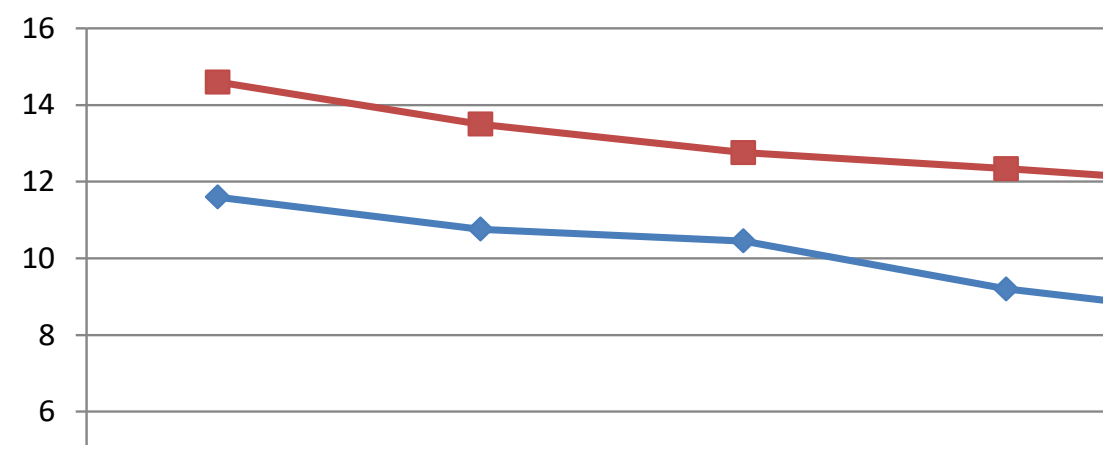


Висновки. 1. Уніфіковані протоколи надання медичної допомоги пацієнтам з гострим інфарктом міокарда 3 елевацію сегмента ST та без елевації сегмента ST, які діють в Україні на даний момент відповідають міжнародному стандарту.

2. Показники смертності від гострого інфаркту міокарда в Україні залишаються вищими, ніж у Словацькій Республіці.

3. Для зниження показника летальності пацієнтів з гострим інфарктом міокарда необхідно покращити укомплектування кардіологічних бригад швидкої медичної допомоги відповідними препаратами, продовжувати розбудову кардіологічних центрів у країні та їх забезпечення необхідним устаткуванням та безкоштовними стентами.

4. Внести зміни до діючого протоколу надання медичної допомоги пацієнтам із гострим інфарктом міокарда без елевації сегмента ST, які стосуватимуться обов'язкового виконання коронарографії в плановому порядку після проведеного лікування.

5. Покращити санітарно-просвітницьку роботу серед населення про своєчасне звернення за медичною допомогою при больовому симптомі.

Інформація про конфлікт інтересів. Автори заявляють про відсутність конфлікту інтересів при виконанні наукового дослідження та підготовці даної статті.

Інформація про фінансування. Автори гарантують, що вони не отримували жодних винагород у будь-якій формі, здатних вплинути на результати роботи.

Особистий внесок кожного автора у виконання роботи:

Ряшко В.І. - збір матеріалу, статистична обробка даних, підготовка та написання частини тексту.

Фатула М.I. - розробка концепції і дизайну дослідження, аналіз отриманих даних, редагування.

\section{Список використаної літератури}

1. Andriivska SO. Hostryi koronarnyi syndrom: mizhnarodnyi dosvid i suchasni pozytsii. Liky. 2015;2(23):2429. [In Ukrainian].

2. Kravchenko AM Dohospitalnyi trombolizys pry hostromu koronarnomu syndromi, mozhlyvosti pokrashchyty vyzhyvannia. Medytsyna neotlozhnokh sostoianyi. 2013;2:89-94. [In Ukrainian].

3. Rekomendatsyy ESC po vedenyiu bolnыkh s ynfarktom myokarda s podъemom sehmenta ST. Medicine Review. 2008;5(5):818. [In Russian].

4. Rekomendatsyy Evropeiskeho Kardyolohycheskoho Obshchestva po provedenyiu perkutantnыkh koronarnukh vmeshatelstv. K. 2005:12,13,16,27. [In Russian].

5. Uriadovyi portal. Ministerstvo okhorony zdorov'ia Ukrainy. Bezoplatne stentuvannia, reperfuziini merezhi, anhiohrafy: yak zminiuietsia systema nadannia dopomohy patsiientam z khvorobamy sertsia. Rezhym dostupu: https://www.kmu.gov.ua/ua/news/bezoplatne-stentuvannya-reperfuzijni-merezhi-angiografi-yakzminyuyetsyasistema-nadannya-dopomogi-paciyentam-z-hvorobami-sercya. 09.04. 20019 r. [In Ukrainian].

6. 2015 ESC Guidelines for the management of acute coronary syndromes in patients presenting without persistent ST-segment elevation. European Heart Journal. 2016;37:267-315.

Стаття надійшла до редакції: 30.01 .2019 р. 